\title{
How to Return from Flight
}

I withdrew temporarily until I had [time to] reflect and console my grief, but now I am commissioned to exalt him among the people of the church and the seat of the presbyters. If the temporary withdrawal deserved blame, this worthy return pardons [it].

—GREGORY OF NAZIANZUS, DEFENSE OF HIS FLIGHT

The wildness of the desert landscape held theological and cultural significance within Christian memory well before and after Athanasius of Alexandria fashioned his city in the Nitrian desert. Within the Christian imagination, the desert was the ultimate training ground for Christian fortitude. Like Athanasius, other early Christian writers would capitalize on the theological as well as culturally significant space of the desert to imagine and reconstruct their heroes of the past. These men and women of faith were not simply tested in the desert during peak periods of persecution. They also had to find the courage to return. For someone like Gregory of Nazianzus, Christian flight always carried with it uncertain dangers. The charge of cowardice, which we have addressed before, was always a step or two behind the fleeing saint. These flights into the wild, therefore, could not be an end in themselves. True Christians must carry the knowledge of their desert sojourn with them back to the city. According to Gregory, it is only after one returns that the full benefits of Christian flight are realized and, more importantly, justified. As we will come to see, Gregory's legacy as a man in flight is dependent upon this logic.

In this chapter, we will explore how Gregory's biographical depictions of both Basil of Caesarea and Athanasius of Alexandria as fleeing men were paramount to his theological offensive in and around Constantinople. We will begin by examining how Basil's familial link to other fleeing men and women and then his own flight to Pontus helped secure his victory over heresy. Then we will turn to how Gregory promoted Athanasius's exile into the desert. As Gregory narrated

1. Gregory of Nazianzus, Orat. 2.115. Edition: SC 247. Translation in consultation with PG 35:58-59, 513 and NPNF2 7, with modifications. 
it, orthodoxy is intimately tied to ascetic withdrawal. Ultimately, both Basil and Athanasius must return to their respective cities, for it is their return that confirms their authority. And-as he concludes in defense of his own flight-the return is what pardons the flight.

\section{HOW TO REHABILITATE A FAILED BISHOP: GREGORY OF NAZIANZUS}

Gregory of Nazianzus was born around 329, the middle child of three. His elder sister, Gorgonia, and his younger brother, Caesarius, played an integral role in Gregory's autobiographical reflections, as did his influential parents, Gregory the Elder and his beloved mother, Nonna. As a highly educated man, Gregory reflects the best of what late antiquity had to offer. His studies took him to the epicenters of Graeco-Roman education: Caesarea, Caesarea Maritima (Palestine), Alexandria, and Athens. It was in these influential cities that he developed as a rhetor and fierce intellectual.

Gregory's education was not without its controversy, however. As Neil McLynn and Susanna Elm have both argued, it was at Caesarea Maritima that Gregory and his friend Basil may have first encountered (however briefly) Origen of Alexandria's works and possibly purchased a copy of the Philocalia. ${ }^{2}$ Origen's ideas and legacy would later haunt Gregory, among others, in powerful ways. ${ }^{3}$ Nevertheless, Gregory was a man of the city and his greatest works were written and influenced by all it had to offer.

Gregory was as well connected as he was well traveled. He seemed to collect famous friends as he did controversial texts. While studying in Athens, Gregory met Basil, the future bishop of Caesarea. ${ }^{4}$ According to Gregory, the two became inseparable and continued to influence one another throughout their literary and ecclesiastical careers. ${ }^{5}$ And it was Basil's brother, Gregory of Nyssa, who

2. For detailed assessment of the scholarly discussion on Gregory and the Philocalia, see Susanna Elm, Sons of Hellenism, Fathers of the Church: Emperor Julian, Gregory of Nazianzus, and the Vision of Rome (Berkeley: University of California Press, 2012), nn. 22-23, 34. Mark DelCogliano has recently challenged this claim in his "Tradition and Polemic in Basil of Caesarea's Homily on the Theophany," Vigiliae Christianae 66 (2012): 54. DelCogliano's article provoked a response from Adam Rasmussen, "Basil of Caesarea's Uses of Origen in His Polemic against Astrology," Zeitschrift für Antikes Christentum 18, no. 3 (2014): 472. The encounters of both Gregory and Basil with Origen's teachings are found in Sozomen, Eccl. Hist. 6.17.

3. See chapter 4 for a discussion on the Origenist controversy and its influences on John Chrysostom's biographers and many other figures who traveled between Alexandria and Constantinople. Sozomen's easy acceptance of Origen's influence is also quite telling once we examine the history of the Constantinopolitan see in his ecclesiastical history.

4. Not to be confused with the so-called homoiousian bishop of Ancyra.

5. Neil McLynn has called into question just how close Basil and Gregory actually were. See McLynn, “Gregory Nazianzen's Basil: The Literary Construction of a Christian Friendship," Studia Patristica 37 (2001): 178-93. 
would eventually complete their triad as the Cappadocian fathers. Their friendship-and a rapidly growing social network of pro-Nicene heavy hitters-was remembered as what fiercely defended Asia Minor against the throes of heresy. It was no coincidence, according the later ecclesiastical historians, that the epic battle over Nicene Christianity came to a head in the eastern capital of the Roman Empire, Constantinople.

Gregory's extensive literary corpus frequently alludes to the support provided by influential friends in the surrounding powerful cities of Asia Minor. While at times hard to retrace, his biographical works provide us with a glimpse into the complex theological battles that were waged on the road from Nicaea to Constantinople. It is unsurprising, then, that this elite man from the small town of Nazianzus quickly rose through the ranks, even to briefly take over the coveted role as bishop of Constantinople. His influence and connections continued to bolster his reputation. Even after his failed and brief tenure in Constantinople, his notoriety would continue to follow him and eventually win him the name "Gregory the Theologian."

As a gifted rhetorician, he made full use of his talents to laud the achievements of his friends as well as his theological allies. His use of panegyric, for example, has been well documented and will occupy our attention later in this chapter. But before we turn to his impressive display of oratorical skill, we must first examine his journey to Constantinople and why it was possible for this particular man not only to inherit this powerful episcopal seat but also to help establish a formidable brand of Nicene Christianity firmly within its walls.

Much like Alexandria, the city of Constantinople occupies an important place within Christian memory, particularly in the ecclesiastical histories of the fifth century. And, as we found in the previous chapter, the locations and the borders of orthodox spaces are infused with cultural and theological meaning in the growing battle over Nicaea. Here we will begin to explore how Gregory of Nazianzus played an important role in constructing the Constantinopolitan legacy as a pro-Nicene one that later historians would look to as their guide. This process was due in no small part to Gregory's links to Athanasius and his exilic discourse. His claim over the Alexandrian legacy, however, would not go unchallenged.

As we will come to see, Gregory, either keen to take a risk or pressured into the position, made ample use of other theologically-infused spaces to shore up Constantinople's orthodox reputation, as well as his own. ${ }^{6}$ As Elm has recently

6. The naming of Constantinople as a "New" or "Second" Rome is contested prior to 381. It is commonly accepted that the title is confirmed at the Council of Constantinople. Lucy Grig and Gavin Kelly also reference Themistius, who, in a speech before Constantius II in 357, claims that Rome and Constantinople "share their Fortune (tychē) and name, the old and the New Rome (Or. 3.42a, 42c)." See Grig and Kelly, "From Rome to Constantinople," in Two Romes: Rome and Constantinople in Late Antiquity, ed. Lucy Grig and Gavin Kelly (Oxford: Oxford University Press, 2010) 11. They also cite Socrates, Eccl. Hist. 1.16.1; CTh 13.5.7, 1; and a poem by Publilius Optatianus Porphyrius Carmina 4.6. See also Grig and Kelly, "From Rome to Constantinople," 11n39, for debates concerning earlier references. 
noted, the urban competitions taking place in Constantinople, Alexandria, and Antioch-and, I would add, Nicomedia-are instructive as we assess the growing significance and overlap of imperial and theological import in the aftermath of the council of Nicaea. ${ }^{7}$ Unfortunately, most of our evidence comes from later historians. We will return to the historiographical exercise of the later pro-Nicene historians at a later point. For now, we will concentrate on the various ways the city of Constantinople and its embattled episcopacy took on new levels of theological and political significance in a very short period of time.

\section{HOW TO CONSTRUCT A MODEL CITY: CONSTANTINOPLE}

Constantinople's rapidly growing wealth and size made the city an ecclesiastical force in the Roman Empire during the late fourth and fifth centuries. ${ }^{8}$ The city, given its name by Constantine, was founded in $324 \mathrm{CE}$ and dedicated by the emperor on May 11, 330. And while it was never the primary residence of Constantine-he appeared to favor the neighboring city of Nicomedia-it grew significantly until his death in $337 .{ }^{9}$ Soon after that, its population expanded dramatically, and the city was adorned with art installations and statues imported from across the empire. ${ }^{10}$ Constantinople was soon regarded as the seat of emperors-Julian was the first to be born there-although it was not consistently inhabited by imperial rulers until Theodosius in $380 .{ }^{11}$ However, Constantius II is said to have brought the relics of Timothy, Luke, and Andrew to the city in 356-357, and the bones of Constantine were said to have been transferred to Constantinople shortly after his death. ${ }^{12}$ Finally, church buildings were commissioned during this period, which culminated in construction of the basilica of Hagia Sophia, which transformed Constantinople into a holy city in its own right.

7. Elm, Sons of Hellenism.

8. For a helpful material reconstruction of the city grid enabled by a close examination of the layout of the streets, see Albrecht Berger, "Streets and Public Places in Constantinople," Dumbarton Oaks Papers 54 (2000): 161-72.

9. For a description of the building campaign, see Hartmut Leppin, Theodosius der Große: Aufdem Weg zum christlichen Imperium (Darmstadt: Primus, 2003), 188-201.

10. For material evidence, see Carlos Machado, "Aristocratic Houses and the Making of Late Antique Rome and Constantinople," in Two Romes: Rome and Constantinople in Late Antiquity, ed. Lucy Grig and Gavin Kelly (Oxford: Oxford University Press, 2012), 136-58. Machado explores the urban development of both Rome and Constantinople and provides useful biographical references in his footnotes, as well as helpful maps of aristocratic domiciles. For references to Constantinople, see especially $154-58$.

11. Brian Croke, "Reinventing Constantinople: Theodosius I's Imprint on the Imperial City," in From the Tetrarchs to the Theodosians: Later Roman History and Culture, 284-450, ed. Scott McGill, Cristiana Sogno, and Edward Watts, Yale Classical Studies 34 (Cambridge: Cambridge University Press, 2010), 241-42.

12. We will explore this detail in chapter 5 . 
The overlap of imperial fanfare with Christian ritual has been extensively studied. Lucy Grig and Gavin Kelly have pointed out that Constantinople's history as the chosen capital of Constantine symbolized the triumph of Christianity, imagined or real, and placed it on equal footing with Rome. ${ }^{13}$ The Nicene legacy instilled by Theodosius I marked the city as theologically significant, and it continued to thrive well beyond that emperor's death in $395 .{ }^{14}$ Whether or not Constantinople even stood as a competitor, let alone a usurper, of Rome's powerful influence is certainly debatable. But it is clear that Constantinople's champions certainly believed it to be a political and ecclesial contender among the surrounding imperial cities of the Eastern Roman Empire. More importantly, the power its bishop held was not to be overlooked. Indeed, by the late fourth century, Constantinople stood as a strong rival not just to Rome but also to Alexandria in terms of its theological and political significance within Asia Minor. This ongoing race for theological influence would be a source of woe for Gregory and those who followed in his footsteps. ${ }^{15}$

Before his appointment to Constantinople, Gregory was given the bishopric of Sasima, although he never actually appears to have taken up his charge there. Instead, he spent a short period tending to his ailing parents in Nazianzus; after their deaths, he fled to Seleucia for three years. ${ }^{16}$ By this point in his life, he was already well known as a man in flight and extremely hard to pin down. As Bradley Storin has argued, many of Gregory's acquaintances in and around Asia Minor persuaded him to take up residence in Constantinople. ${ }^{17}$ Members of the Antiochene council in 379 would help to position him as the favored pro-Nicene representative in the theological battleground. ${ }^{18}$ It is this role that would eventually lead to his election as its bishop.

According to the fifth-century historian Socrates, it was Theodosius I and not the Antiochene council who initiated his election as bishop of Constantinople,

13. Grig and Kelly, "From Rome to Constantinople," 14.

14. Constantinople's developing supremacy as the uncontested capital of the empire is hotly debated. Recently, scholars have tried to counteract persistent methods of research that take the vantage point of teleological interpretations espoused in monumental works such as Edward Gibbon's History of the Decline and Fall of the Roman Empire. They also seek to debunk mythic claims built around documents like the Donation of Constantine, a commonly acknowledged forgery. See, for example, Grig and Kelly, "From Rome to Constantinople," 3-30. Croke, "Reinventing Constantinople," 247, also draws out Theodosius's efforts to consolidate the various factions within Constantinople during his reign: "Faced with a plethora of church practice and belief that had produced a range of competing congregations centered on particular churches and a deeply factionalized community, Theodosius' instinct was to bring them all together and let them find their common ground."

15. See chapter 3 for a discussion of John Chrysostom's controversial election.

16. Gregory of Nazianzus, Carm. 2.1.2.547-51.

17. Bradley Storin, "The Letter Collection of Gregory of Nazianzus," in Late Antique Letter Collections: A Critical Introduction and Reference Guide, ed. Cristiana Sogno, Bradley K. Storin, and Edward J. Watts (Berkeley: University of California Press, 2017), 82.

18. Storin, "Letter Collection," 82, 96n12. 
only a few days after his own triumphant arrival. ${ }^{19}$ And Sozomen remarks that Theodosius gave the then bishop of Constantinople, Demophilus (frequently referred to as a homoian or simply an Arian), the opportunity to take up Nicaea's cause or leave. ${ }^{20}$ After informing his community of the edict, Demophilus encouraged his disciples to follow him outside the city walls. To make his reasoning perfectly clear, he invoked Matthew 10:23: "When they persecute you in one town, flee to the next." ${ }^{21}$ We will return to this verse at a later point. For the time being, regardless of who initiated Demophilus's replacement, Gregory never sat comfortably on the bishop's throne. ${ }^{22}$

To be fair, the story is further complicated by the series of rotating bishops prior to Gregory's ill-fated election to the see of Constantinople. The battle over the Constantinopolitan patriarchate was fierce from its earliest inception. ProNicene historians, for instance, will extol Alexander of Constantinople as the fiercest defender of Nicaea's legacy in the new Rome and claim him as its first official bishop. Socrates and Sozomen both state that it was Alexander alone who resisted Arius's readmittance into the church despite threats of banishment from Constantine. And, according to Athanasius, it was Alexander's prayers that brought about Arius's timely death right before his readmittance to the faith. ${ }^{23}$

But the race for control began soon after Alexander's death in 337. Rafal Kosinski has most recently provided a sketch of the subsequent power grab that took place. ${ }^{24}$ Between 337 and 339, Paul I and Macedonius I both vied for the position, with Paul as the favored candidate. In a curious move that will remain a sore spot in pro-Nicene memory, Eusebius of Nicomedia temporarily won the day (ca. 339-341). ${ }^{25}$ This detail is often downplayed by later historians or deemed a

19. Socrates, Eccl. Hist. 5.7. For Theodosius's calls for a unified Christianity, see CTh 16.1.2. For notes on whether Theodosius initiated a pro-Nicene position early on, see Elm, Sons of Hellenism, $403 n 93$. We will engage Socrates in more detail in chapter 5.

20. Sozomen, Eccl. Hist. 7.5.

21. Gregory's rival is also mentioned in Basil's letter, Ep. 48. Lester L. Field also believes Gregory takes a jab at Demophilus in his In Praise of Athanasius, when Gregory remarks, "For it is not the intruder, but he whose rights are intruded upon, who is the successor, not the lawbreaker, but the lawfully appointed, not the man of contrary opinions, but the man of the same faith; if this is not what we mean by successor, he succeeds in the same sense as disease to health, darkness to light, storm to calm, and frenzy to sound sense" (Gregory of Nazianzus, Orat. 21.8). See Field, On the Communion of the Damasus and Meletius: Fourth-Century Synodal Formulae in the Codex Veronensis LX (Ontario: Pontifical Institute of Mediaeval Studies, 2004), 159n88.

22. For a list of scholars who view Gregory's episcopacy as a failure, see Elm, Sons of Hellenism, $5 \mathrm{n} 15$.

23. Athanasius, Ep. mort. Ar. 4. Edition: Hans-Georg Opitz (ed.), Athanasius Werke II, Band 1, Erster Teil: Die Apologien (Lfg. 1-7) (Berlin: de Gruyter, 1940), 178-80.

24. For the most recent attempt to trace the many appointments and exiles of the Constantinopolitan bishops, see Rafal Kosinski, "The Exiled Bishops of Constantinople from the Fourth to the Late Sixth Century," Studia Ceranea 5 (2015): 231-47.

25. Kosinski helpfully traces the four exiles of Paul: 337, 341, 342-343, and 350-351; see Kosinski, "Exiled Bishops," 232n3. The episode of Macedonius's forced appointment is suspect given that the 
brief dark period within the history of the holy city, and it is one to which we will return. We might recall from the previous chapter that Eusebius appointed George of Cappadocia as Athanasius's replacement while he was firmly in control at Constantinople, with the full support of Constantius II. We hear of George's appointment in several of Athanasius's works, including the Defense before Constantius and Defense of His Flight. As David Gwynn has noted, both George and his successor, Gregory, are identified as "Eusebians" (hoi peri Eusebion) who are hirelings of the Arian party. ${ }^{26}$ It appeared as if the anti-Nicene party would win the day in both Alexandria and Constantinople, a point that Gregory contested in his oration, discussed below. Nevertheless, Eusebius's tenure as the bishop of Constantinople was a resounding success. Unlike Arius, Eusebius died unmolested and uncontested, a detail that remained embarrassing for later pro-Nicene historians.

Yet Eusebius was quickly replaced by Paul, a presumed pro-Nicene supporter, in what would later be described as a momentary reprieve. But Paul's grasp on the episcopacy, like that of Gregory later in his career, was a tenuous one. He was immediately ousted by the Arian-leaning Macedonius, whose seizure of the office was described as a riotous affair that resulted in a bloodbath. It took nothing short of an imperial escort to transfer Macedonius safely to the great Constantinopolitan Church. According to other pro-Nicene historians, an anti-Nicene stronghold remained in power until the triumphant arrival of Gregory of Nazianzus. ${ }^{27}$

Admittedly, this narrative is highly suspect, due to its pro-Nicene slant. What camp each bishop aligned himself with between the death of Alexander and the appointment of Eusebius of Nicomedia would certainly shift and change as new charges of heresy from all sides of the debate were hurled against each appointment. For our purposes, we should consider in hindsight how Constantinople was transformed into a beacon of orthodoxy once Gregory of Nazianzus, that defender

evidence we have comes from later pro-Nicene historians who are invested in preserving Paul as the true inheritor of the see and not his Arian counterpart.

26. David M. Gwynn, The Eusebians: The Polemic of Athanasius of Alexandria and the Construction of the "Arian Controversy" (Oxford: Oxford University Press, 2007), 54.

27. Macedonius was followed by Eudoxius in $360 \mathrm{CE}$, after Macedonius appears to have had a falling out with Constantius II (Socrates, Eccl. Hist. 2.38 and Sozomen, Eccl. Hist. 4.21). Evagrius briefly followed Eudoxius in 370 but was quickly replaced by Demophilus, although Evagrius appears to also have remained an active competitor. But with the arrival of the emperor Theodosius I, according to Sozomen, Demophilus fled the city along with his supporters and set up a church just beyond the city walls, a detail we will explore later. For recent works debating Demophilus's flight, see R. Malcolm Errington, "Church and State in the First Years of Theodosius I," Chiron 27 (1997): 21-72; Neil McLynn, "Moments of Truth: Gregory of Nazianzus and Theodosius I," in From the Tetrarchs to the Theodosians: Later Roman History and Culture, 284-45o CE, ed. Scott McGill, Cristiana Sogno, and Edward Watts, YCS 34 (Cambridge: Cambridge University Press, 2010), 215-39; and Susanna Elm, "Waiting for Theodosius, or the Ascetic and the City: Gregory of Nazianzus on Maximus the Philosopher," in Ascetic Culture: Essays in Honor of Philip Rousseau, ed. Blake Leyerle and Robin Darling Young (Notre Dame: University of Notre Dame Press, 2013), 185-86. 
of Nicene Christianity, took control. Much as it was for Athanasius, it is Gregory's own posturing and narration of the events that promoted this picture and made it the one later writers would adopt. It is worth emphasizing that only after the proNicene ecclesiastical historians picked up the storyline was Gregory's brief time in Constantinople remembered as a success. During Gregory's lifetime, however, this claim would be an embattled one.

Many of Gregory's problems appear to stem from his alliance with members at the Antiochene council, specifically his ties to Meletius of Antioch and his supporters. It is quite possible that the same group responsible for Gregory's appointment in Constantinople was also responsible for his inevitable flight. By aligning himself with Meletius rather than the Alexandrian favorite, Paulinus, Gregory placed himself at odds with Alexandria. I argue that this relationship was further strained by his insistence on claiming Athanasius's legacy upon his appointment to Constantinopolitan see. As Storin has recently pointed out, it was Timothy of Alexandria who first called into question Gregory's legitimacy as the rightful bishop of Constantinople, a connection we should not overlook and which I will make all the clearer in the next chapter. Timothy directly challenged Gregory's claim by invoking the fifteenth canon of Nicaea, "which prohibited the translation of bishops, priests, and deacons from one see to another." ${ }^{28}$ Although Gregory never took up his post in Sasima, it was an appointment he clearly could not escape. After a mere few months as the reigning bishop of Constantinople and president of the Council of Constantinople, Gregory was forced to step down and flee once again. For our purposes, it is the complex alliances forged between Alexandria, Antioch, and Constantinople (and Nicomedia) that continued to play a major role in the development of the Nicene legacy. Gregory is hardly the first to draw the attention and ire of Alexandria, and the outcome would soon become a familiar one.

Tension arose between Constantinople and Alexandria when Gregory claimed the Athanasian legacy and exilic discourse. In pro-Nicene memory, Gregory of Nazianzus is one of the first to shape Athanasius's story of exile as a sign of Christian orthodoxy, in his Oration 21, also known as In Praise of Athanasius, delivered in Constantinople in 380. ${ }^{29}$ Athanasius's theory of the desert and larger exilic discourse is revived and altered in this text and later championed by pro-Nicene ecclesiastical historians.

Gregory's adoption of Athanasius's exilic discourse in In Praise of Athanasius appears all the more significant when that text is read alongside his more famous panegyric, Oration 43, or In Praise of Basil the Great. In both works, we find remarkable links to the tradition of Christian flight and the heterotopic spaces of the desert.

28. Storin, "Letter Collection," 82. The account is found in Gregory of Nazianzus, Carm. 2.1.2.1810.

29. Gregory of Nazianzus, Orat. 21. Edition: PG 35:1081A-1128C and SC 270. Translations of this oration often modified slightly. 
As we will come to see, the mythical desert must eventually be left behind as both men return to their respective cities to secure their orthodox legacies. But before we turn to this text and its significance for later historians, we will examine Gregory's broader theory on Christian flight, because it is in the space between flight and episcopal duty that we find his most ardent defense of (his) orthodoxy.

\section{A MODEL EXILE: IN PRAISE OF BASIL THE GREAT}

From an early stage in his Christian journey, Gregory was a man in flight. The tugof-war between philosophical withdrawal and civic responsibility, captured in the epigraph with which this chapter began, would continue to haunt his many theological and, later, explicitly apologetic works. Gregory would eventually reread Christian flight as a temporary withdrawal in order to help preserve an orthodox reputation for himself as well as those with whom he associated. ${ }^{30}$ This rhetorical move is seen most clearly in his panegyrics on Basil of Caesarea and Athanasius of Alexandria. ${ }^{31}$

Basil of Caesarea, whose defense of Nicene politics in Asia Minor and ties to Alexandria played an important role in the pro-Nicene narrative read back into this particularly tense moment. Like Gregory, Basil's involvement with Antiochene politics would temporarily put him at odds with the pro-Athanasian narrative. As has been frequently noted, Basil was a firm supporter of two significant exiles, Eustathius of Antioch and Meletius of Antioch. This theological and political alliance temporarily called into question Basil's allegiance to Nicaea, due to questionable theological claims of those men. ${ }^{32}$

Between 330 and 415, in the aftermath of Eustathius's exile and the Council of Nicaea, Antioch would host anywhere from two to three competing bishops at a time, for reasons that are mixed and filled with intrigue. There appears to have been a split down geographic as well as theological party lines, as many vied for this bishopric. In Athanasius's On the Synod and Tome of Antioch we hear of significant, albeit failed, efforts to bring about a compromise among competing parties. For instance, Basil's stubborn support of Eustathius and, later, Meletius would put him at odds with the supporters of Paulinus, who aligned themselves with Alexandria. This ardent defense of the wrong party, according to Philip Rousseau, put Basil's orthodoxy on trial. On his way to meet Eustathius in 373 , for example, he

30. For Gregory's own efforts to rehabilitate his reputation in the period immediately after his failed tenure as bishop of Constantinople, see Bradley Storin, "In a Silent Way: Asceticism and Literature in the Rehabilitation of Gregory of Nazianzus," Journal of Early Christian Studies 19, no. 2 (2011): 225-57.

31. See, in particular, Elm, Sons of Hellenism, 213-24.

32. When we turn to the complicated history of John Chrysostom and his links to Antioch in the next chapter, we will continue to unravel the various ways in which the ties of Gregory and Basil to Antioch will eventually be reconciled and explained away. 
was asked to draft a statement of orthodoxy to clarify his theological position..$^{33}$ We will spend more time on the Antiochene divisions at a later point, but for now it is Basil's decision to support Meletius over against Paulinus that required a great deal of revisionary work by his most famous biographers, Gregory of Nyssa and Gregory of Nazianzus. ${ }^{34}$

There is a marked contrast between Gregory of Nyssa's Encomium on His Brother Basil (ca. 380-381) and Gregory of Nazianzus's In Praise of Basil the Great (Orat. 43) (382). In the former, the brother of the famed bishop of Caesarea is compared to the most exemplary biblical figures, chief among them the apostle Paul. As David Konstan highlights, this comparison eclipses his familial relationships. While Gregory of Nazianzus began with a narration of Basil's earthly attachments, as would be expected, Gregory of Nyssa lifted his brother out of his earthly lineage - and any possible scandals those links might bring about-and intentionally transplanted Basil into a biblical lineage in order to stress that he was a man from a different realm. ${ }^{35}$

Gregory of Nazianzus also stressed Basil's placelessness in his eulogy. But rather than strip him of his illustrious and elite lineage, Gregory instead emphasized his legacy as one among many fleeing saints, not unlike Athanasius's Defense of His Flight. ${ }^{36}$ Gregory appealed to Basil's familial heritage as a lineage filled with men and women who flee from the city into the wilderness to train and to learn that no earthly attachments, no homeland, and no creaturely comforts afforded by one's social status will effectively cultivate the virtues of a true Christian. Instead, the practice of ascetic withdrawal is what truly prepares the Christian for life's many trials. One does not stay in the desert, however; one must return to the city to do battle. Gregory of Nazianzus thus interprets Christian flight-here understood as a temporary ascetic retreat-as essential to one's training for the clerical office.

In his Oration 43, In Praise of Basil the Great, written a few years after Basil's death in 379, Gregory uses the theme of Christian flight to emphasize his dearly departed friend's virtue. ${ }^{37}$ What stands out in this speech is the way Gregory traces Basil's actions and reputation through his familial lineage to the men and women

33. Philip Rousseau, Basil of Caesarea (Berkeley: University of California Press, 1998), 241.

34. See chapter 6 on the effort to revive Meletius's legacy.

35. David Konstan stresses this placelessness: "His discourse constructs a barrier between Basil, who is written into a sacred text that is not so much ancient as transcendently enduring, and those outside the narrative space, whether the speaker himself or his audience who take Basil as their ideal. There is no communion between these realms: in saying nothing of Basil's family, Gregory is, of course, saying nothing of his own." See Konstan, "How to Praise a Friend," in Greek Biography and Panegyric in Late Antiquity, edited by Tomas Hagg (Berkeley: University of California Press, 2000), 165.

36. See chapter 1.

37. Gregory of Nazianzus, Funeral Oration to St. Basil (BHG 245-Oration 43); Critical ed. and French tr. Jean Bernardi, Gregoire de Nazianze, Discours 42-43, SC 384 (1992); Unless otherwise noted, English translation (with some slight modifications) follows Leo McCauley, Funeral Orations by Saint Gregory Nazianzen and Stain Ambrose, (FC 22) Washington DC, 1953, 27-99. 
who fled during times of persecution. Gregory looks back to their flight as what ushers in and secures Basil's heroism. He concludes that it was their willingness to flee that would model for Basil the virtue of, and even the demand for, Christian flight.

Notably, Gregory differentiates between Christian flight and imperial banishment. One is voluntary and the other compulsory. Imperial banishment, or the threat thereof, was a tool deployed by wayward emperors to compel bishops to bend to imperial rule and, as we saw with Athanasius in the previous chapter, served as a sign of Christian persecution. Gregory insisted that the true bishop does not fear banishment, because he will have already trained himself in the desert to prepare for his role as a Christian leader. Imperial threats of compulsory exile, then, have no hold on those bishops who have already wandered.

Gregory of Nazianzus's eulogy follows the standard formula for laudationes funebres. ${ }^{38}$ The first half of the speech praises Basil's ancestral lineage and describes his illustrious education. Then the text concludes with many details of his life, which continue to emphasize his virtue. What stands out in this eulogy, and is the focus of our study, is how Gregory characterizes exile as a desert askesis, which was also the conclusion of his earlier panegyric on Athanasius. We will begin with Gregory's eulogy on his friend Basil, although it is a later text than In Praise of Athanasius, in order to stress how the desert functions as a training ground for the Christian elite. We will then turn to his earlier oration on Athanasius to see how Gregory alters Athanasius's discourse to emphasize the temporary nature of Christian flight. It is this model that will set the standard for later biographical inheritors of Athanasius's legacy as an exile, and we will soon see why. While Athanasius's legacy as an orthodox exile during his own lifetime is linked to the language of persecution - a strategy Gregory will also use-the orthodox bishop ultimately must return triumphant to substantiate that claim. And he must return not to just any city, but to one bound to the legacy of Nicaea.

In his funerary speech on Basil the Great, Gregory states that it is possible to capture the value of a man in two ways: we can look to those traits inherited from a man's pedigree, and we can look to how that legacy influences the man's actions throughout his life. To begin, Gregory turns to the Christian persecutions under Maximinus (303-313). As we might expect, he stresses that martyrdom should be neither sought voluntarily nor avoided. It appears that Tertullian's charge of cowardice is never far behind. But the decision to flee is not an easy one, especially for the social elite. Gregory is careful to stress that when Basil's illustrious ancestors decided to escape, they chose the harder course. He describes their flight to the secluded location of Pontus in the following ways: "For their flight was exceedingly prolonged, to about seven years or a little more, and their mode of life, delicately nurtured as

38. For a description of the standard formula of a funeral oration, see Konstan, "How to Praise a Friend," 166-67. 
they were, was straitened and unusual, as may be imagined, with the discomfort of its exposure to frost and heat and rain. And the wilderness allowed no fellowship or converse with friends - a great trial to men accustomed to the attendance and honor of a numerous retinue" (Orat. 43.6). ${ }^{39}$ Here Gregory explains that those who were accustomed to the luxuries of life and constant companionship in their social circles were forced into far harsher conditions than the average Christian. These men and women were not used to living without the many comforts afforded to their class.

Gregory frequently compares their wandering to Israel's exodus. Without the comforts of Egypt, the Israelites also wandered with constant threat of starvation and exposure to the most abhorrent of living conditions. Like the Israelites, Basil's ancestors endured their sojourn into the wilderness in order to humble themselves and better prepare for their return. And because they suffered during their wandering, their children would benefit from their example, as they faced their own battles in their homeland. Basil's immediate family likewise benefitted from the suffering endured during their ancestors' retreat. It is no coincidence, Gregory argues, that Basil's family lived lives that reflected this flight to Pontus. All the members of Basil's family dedicated themselves to an ascetic lifestyle, as if they too were in the wilderness. The legacy of the flight was thus passed on to each child, Gregory insists, and it served as the very foundation of Basil's virtue and success as the future bishop of Caesarea.

With this past of Christian flight in mind, Gregory turns to Basil's childhood and intellectual training. Exceedingly well educated and ambitious, Basil stood out from an early age. Once he and Gregory encountered one another at school, their friendship blossomed instantaneously, although it was only in Athens that the two men became inseparable. In many instances, Gregory describes their friendship as uneven. He had to protect Basil from the cruelties of adolescence, as when he claims to have sheltered Basil from a hazing ritual at the baths and, later, a conspiratorial attempt to humiliate Basil in an oratorical game of logic. In his early years at least, Gregory made every effort to go to battle on his friend's behalf, for the love shared between the two men was superhuman: "We seemed to have one soul inhabiting two bodies" (Orat. 43.20). It was with great pain and heartbreak that the two young men were eventually separated by the responsibilities of adulthood, and Gregory could no longer protect his dear friend.

Halfway through the speech, Gregory describes one of the first major conflicts Basil was forced to endure alone. He appears to have clashed with the bishop of Caesarea (whom Gregory does not name). Ill equipped to face this challenge on his own, Basil fled to Pontus. Thus it is not as a bishop but as a committed ascetic that Basil's initially flees, a notable contrast with Athanasius. He was welcomed in the familiar deserted landscape of Pontus, Gregory states, by Elijah and John,

39. Gregory favors the terms ermia and oros to describe the location of their retreat. Like Athanasius, he uses the terms interchangeably. 
"those professors of austerity" (Orat. 43.29). This retreat transformed Basil. It is while he was in the desert that Basil decided to dedicate himself to the clerical office as a priest. His return is thus made all the more glorious. Now, Gregory proclaims, Basil was able to withstand any opposition. And he returns to Caesarea to face his greatest challenge yet: he must take on a warring, heretical emperor.

The emperor Valens, who also goes unnamed in this text, is described as "most fond of gold and most hostile to Christ, infected with these two most serious diseases, insatiate avarice and blasphemy; a persecutor in succession to the persecutor [Valentinian I], and in succession to the apostate [Julian]" (Orat. 43.30). Valens was a rueful opponent, indeed, and one worth returning from the desert to take on. Trained in the desert and no longer in need of defense from his childhood protector, Gregory, Basil stands boldly as the defender of the church. We are to conclude that his retreat was both necessary and beneficiary, as it guaranteed his victory. ${ }^{40}$

While Basil waged his epistolary war, we learn that other defenders of the faith were cast out of their bishoprics. The enemy, Gregory reports, used a variety of attacks: "Exiles, banishments, confiscation, open and secret plots, persuasion (where time allowed), [and] violence (where persuasion was impossible)" (Orat. 43.46). Gregory is careful to make a distinction between forced displacement and temporary retreat. The former is a weapon used against the church; the other, Christian flight, is described as a time of training that prepares the Christian soldier for battle. While Basil's conflict with Valens raged on, he came into contact with a formidable foe: an imperial representative baptized by the "other party" - in other words, a heretic at the service of the empire. This prefect attempted to intimidate Basil by threatening him with traditional forms of Christian persecution, namely, violence and exile. Basil, however, scoffed at these threats: "'Confiscation, banishment, torture, death. If there is nothing else', said Basil, 'threaten me with that, too, for none of these you mentioned can affect me. . . . As for exile, I do not know what it is, since I am not circumscribed by any place nor do I count as my own the land where I now dwell or any land into which I may be cast. Rather all belongs to God, whose passing guest I am.'” (Orat. 43.49). The false Christian, Gregory announces, has met his match. No threat of violence or banishment would stir the true Christian. Basil carried with him the memory of the desert. He knew that his authority was neither manmade nor tied to any one space. No threat of displacement could frighten him, because he had already faced the wildness of the desert, and he carried that knowledge with him wherever he went.

40. Gregory of Nazianzus, Orat. 1, 2, 26, 33; Ep. 107-14, 116-19; and Carm. 2.1.1.34-48, also uses the language of spiritual purification as a repetitive act, due to the nature of the ecclesiastical office, which exposes one to constant pollution. The need for retreat to expunge this sinful pollution further supports my assessment of Gregory's desire to flee and to return ready for battle. I am grateful to Bradley Storin for drawing my attention to this point in private correspondence and for his helpful feedback on this chapter. 
Gregory states that even the emperor was impressed with Basil's emboldened response, "for even the enemy can admire a man's excellence" (Orat. 43.51). Nevertheless, Valens signed a decree calling for Basil's removal, and it appeared that the bishop would soon be dethroned. What Gregory describes next is particularly interesting for our purposes here. Basil was not exiled. Instead, the emperor's son was suddenly struck with an illness. "There was the sentence of banishment, here the decree of sickness. The hand of the wicked scribed was restrained, and the saint was preserved, and the man of piety presents to us by the fever that brought to reason the arrogance of the emperor" (Orat. 43.54). Like the young prince, we soon learn that another has fallen ill. The unnamed prefect standing in as the emperor's liaison was also struck down. Sufficiently humbled, the false Christian then sought out the aid of the saint: "I own that you were in the right; only save me!" (Orat. 43.55). ${ }^{41}$ Gregory triumphantly proclaims that all threats of Basil's removal were quickly forgotten. Basil's faith, forged in the desert, proved too strong for his enemies. The man of the desert won the day. Basil, that virtuous man whose family set an important example of Christian flight, lived his life as an example of their pious legacy. After his own brief retreat, Basil returned empowered with the memory of the desert that undermines the threats of any emperor or heretic.

\section{A MODEL RETURN: IN PRAISE OF ATHANASIUS}

Lived memory of the desert also arises in another funerary speech and focuses on a man we have met in the desert before. Gregory of Nazianzus's lesser-known oration on Athanasius tells us a great deal about not only his theory of Christian flight but also how the Athanasian legacy was intimately tied to a vision of the orthodox city-just not the city we might expect. For Gregory of Nazianzus, the road from Nicaea ends not in Alexandria but in Constantinople. The speech, In Praise of Athanasius, was delivered in 380, on the eve of the seventh anniversary of Athanasius's death. Gregory's account of Athanasius's precarious position in Alexandria signals the politics during the former's shaky tenure in the city of Constantinople and resonates with the instability of so many fourth-century urban episcopacies. Constantinople, Antioch, Alexandria, and Nicomedia stand at the center of the battle over Nicaea's legacy and the Theodosian project. The panegyric was delivered at a time of significant theological uncertainty and provides us with a unique look into how Athanasius's legacy as an exile must be reconciled with his legacy as an ardent defender of Nicaea.

41. This phrase calls to mind other infected and diseased bodies, such as that of the empress Eudoxia in Ps.-Martyrius's Funerary Speech, which I discuss in Jennifer Barry, "Diagnosing Orthodoxy: Ps.-Martyrius's Funerary Speech for John Chrysostom," Journal of Early Christian Studies 24, no. 3 (2016): 395-418. 
Much like Gregory's speech on Basil, this oration follows a standard literary formula that lauds the efforts of the chief subject but, for our purposes, the use of a panegyric simultaneously bolsters the authority of the speaker. ${ }^{42}$ Others have noted, for example, how Gregory's funeral oration on Basil helped to recover his own questionably orthodox reputation after his flight from Constantinople. In this earlier eulogy on Athanasius, the Alexandrian's reputation as a staunch supporter of Nicaea also serves as a way for Gregory to affirm his pro-Nicene position, despite his ties to a pro-Meletian contingent in Antioch. This grand oratory display may have further strained his relationship with Alexandria.

The speech is broken into three parts. The first section is meant to establish Athanasius as the legitimate heir to the Alexandrian patriarchate. The second section then interprets the bishop's desert sojourn, although it departs slightly from Athanasius's own theory of exile. In the third and final section, Gregory recounts Athanasius's glorious return and reaffirms his legitimacy as the one true bishop of Alexandria and champion of Nicene orthodoxy.

Two details are worth noting about this particular speech that will help us to see how Gregory uses Athanasius's theory of exile to establish a pro-Nicene platform. First, Gregory states that he does not intend to write a history of the bishop's life. The professed goal of the speech is to praise the life of a virtuous man whose example is worth glorifying: "To speak of and admire him fully would perhaps be too long a task for the present purpose of my discourse, and would take the form of a history rather than of a panegyric" (Orat. 21.5). Instead, Gregory's purpose is to focus on specific details in Athanasius's life that demonstrate why he is the rightful heir of Alexandria despite, if not because of, his exile(s).

Second, Gregory is clearly familiar with Athanasius's vita of the desert monk Antony. While expressing his own concerns about composing an entire life of the Alexandrian bishop, he notes that it should be, "for the pleasure and instruction of posterity, as he himself wrote the life of the divine Antony, and set forth, in the form of a narrative, the laws of the monastic life" (Orat. 21.5). This latter detail is significant because it is from the vita that Gregory draws and develops Athanasius's theory of exile as a desert askesis.

As we saw in the previous chapter, the desert functions for Athanasius of Alexandria as a heterotopia. It is a space where he reimagines that place from which he is absent. The city of Alexandria is reflected both in the real and in the imagined space of the desert-the desert has been made into a new city. The desert thus functions as a counterspace to which Athanasius has been banished. It also functions as a space that both reflects and reinvents the space he aspires to reinhabit. The city in the desert, the new Alexandria, is a city devoid of heresy, as the

42. Tomas Hägg, Philip Rousseau, and Christian Høgel, eds., Greek Biography and Panegyric in Late Antiquity (Berkeley: University of California Press, 200o), 1-28. 
incarnated truth-the bishop or monk-transforms the very spaces he inhabits. This process is possible only through Christian flight.

Before we turn to his adoption of Athanasius's work, let us begin where Gregory does, with an explanation on why Athanasius matters in the construction of a pro-Nicene position, when so much of Athanasius's life was spent defending his own legitimacy as the bishop of Alexandria. Gregory starts the speech with a description of Athanasius's background, which includes both a secular and a religious education. "He was brought up, from the first, in religious habits and practices, after a brief study of literature and philosophy, so that he might not be utterly unskilled in such subjects or ignorant of matters that he had determined to despise. ... Thus brought up and trained, as even now those should be who are to preside over the people and take the direction of the mighty body of Christ" (Orat. 21.5-6). Athanasius strikes a careful balance between philosophical study and scriptural knowledge. He neither confuses the two disciplines nor misinterprets the order of importance for correctly managing the body of Christ.

Gregory then states that Athanasius is the true successor to the Alexandrian throne not because he seized his throne through "bloodshed and oppression" (unlike George of Cappadocia or Macedonius of Constantinople), but because he did so in an "apostolic and spiritual manner" (Orat. 21.8). Thus any rival to the Alexandrian throne only provides further proof of Athanasius's legitimacy.

For unity in doctrine deserves unity in office, and a rival teacher sets up a rival throne; the one is a successor in reality, the other but in name. For it is not the intruder, but he whose rights are intruded upon, who is the successor, not the lawbreaker, but the lawfully appointed, not the man of contrary opinions, but the man of the same faith; if this is not what we mean by successor, he succeeds in the same sense as disease to health, darkness to light, storm to calm, and frenzy to sound sense. (Orat. 21.8)

Gregory insists that the doctrinal unity Athanasius represents is grounded in Nicaea. As a promoter of the Nicene cause himself, Gregory identifies the disease and frenzy that threatens to overthrow orthodoxy as Arianism. As is common in heresiological discourse, he provides a stock account of the rise of Arianism: the heresy is born with Arius and then draws in all those heretical instigators who challenge the authority of the council of Nicaea. Much like Athanasius's take on this heretical faction, all who oppose Nicaea are easily lumped together. Following in this logic, Gregory crowns Athanasius as Nicaea's chief defender.

Athanasius's credentials are secured by his philosophical training and his impeccable character. This combination gives him a privileged position among his peers and elders at Nicaea even before he achieves any official rank: "Though not yet ranked among the bishops, he held the first rank among the members of the Council, for preference was given to virtue as much as to office" (Orat. 21.14). By way of contrast, Gregory provides a detailed account of Athanasius's rival, who is a mere vagabond hailing from Gregory's own Cappadocia, the most deplorable of characters: 
There was a monster from Cappadocia born on our farthest confines, of low birth, and lower mind, who by blood was not perfectly free, but mongrel. ... After passing, as exiles, do from country to country and city to city, last of all, in an evil hour for the Christian community, like one of the plagues of Egypt, he reached Alexandria. There, his wandering being stayed, he began his villainy. Good for nothing in all other respect, without culture, without fluency in conversation, without even the form and pretense of reverence, his skill in working villainy and confusion was unequaled. (Orat. 21.16)

George of Cappadocia is the perfect literary foil: As ignorant as Athanasius is learned, George is a mongrel whose patrilineage is mixed, whereas Athanasius is the successor not only of Alexander, but also of the apostle Mark. Most importantly, Gregory asserts, George of Cappadocia is a wandering exile. George is a foreigner, a voluntary exile who wanders from country to country. We might recall that this is the same argument used against Athanasius by the emperor Constantius II (Athanasius, Apol. Const. 31). This detail establishes Gregory's depiction of Athanasius's exile-or, as he will eventually identify it, his "illustrious banishment" - as a mark of pride because it is the result of persecution. The term initially used for exile for both George and Athanasius is fugadeia, but after Athanasius returns from the desert, the term used is ekdemia.

In this speech, exile transforms and is transformed by Athanasius's ascetic retreat. The shift in terms also appears to accommodate his transformative experience in the desert. Athanasius does not wander from country to country or city to city. During his exile, he plants himself among the ascetics of the desert:43 "Then he was in retirement, and arranged his exile most excellently, for he took himself to the holy and divine homes of contemplation in Egypt, where secluding themselves from the world, and welcoming the desert, men live to God more than all who exist in the body" (Orat. 21.19). Even though Athanasius is a displaced bishop, he uses his time in the desert to reaffirm ecclesiastical authority among the desert ascetics. Gregory envisions Athanasius's exile as a serendipitous moment: it provides the desert monks with an authoritative guide to intervene on their behalf. Athanasius not only resides among the desert monks but also instructs them; he acts as a bishop in the desert as if it were the city. Unlike his monstrous counterpart, who sows discord and confusion, Athanasius cultivates peace and unites two seemingly opposing ways of life, those of monastic seclusion and communal life, "by showing that the priesthood is capable of contemplation, and that contemplation is in need of a spiritual guide" (Orat. 21.19).

Gregory goes on to expand upon Athanasius's theory of exile as a desert askesis in order to explain why this time in the desert was necessary. In the Life of Antony,

43. This is an interesting contrast. In Athanasius's Defense before Constantius, Constantius describes Athanasius as a wandering exile in the Letter to the Auxumis Princes, where it is Athanasius who wanders from city to city. 
the desert is a reflection of the Alexandrian city as both a real and imagined space; the desert exists as itself, but it has also been reimagined as a city from which Athanasius is noticeably absent. This literary theme takes on new life as the monk Antony (the bishop in disguise) flees into the desert. Antony both flees into and begins to embody the desert space. The politeia is not only the location of civilization but also, for Athanasius (by way of Antony), a shared way of life found not in the typical city, but in the heterotopic city of the desert.

Gregory builds on this heterotopic vision in his speech. Instead of confining the truth to one physical landscape, like Athanasius's Alexandria reflected in the Nitrian desert, he mobilizes the desert by embedding it in the monk-bishop. The desert askesis transforms into a way of life and serves as a guide for others in a manner that, as David Brakke has argued, defines Athanasius's larger ascetic program: "[Gregory] made Athanasius the virtual founder of monasticism as an organized, disciplined phenomenon within Christianity: 'Whatever he thought was law to them [the monks], and they rejected whatever did not seem good to him. To them his teachings were the tablets of Moses, and their veneration of him surpassed what human beings owe to the saints." 44 The monastic life is not simply about bodily retreat; it is a way of being: "Thus he combined the two, and so united the partisans of both calm action and of active calm, as to convince them that the monastic life is characterized by steadfastness of disposition rather than by bodily retirement" (Gregory of Nazianzus, Orat. 21.20).

To further support his point, Gregory invokes the biblical king David: "Accordingly the great David was a man of at once the most active and most solitary life" (Orat. 21.20). Athanasius, like David, gains a deeper understanding of the contemplative life during his time in the desert and then carries this symbiotic relationship between the active and the solitary with him back into the city. It no longer matters where the bishop resides, because the life of the ascetic always resides in the person of the orthodox bishop. Through Athanasius, ecclesiastical authority is reconfirmed in the desert and activated in the city.

Athanasius's exile is ultimately only temporary. After Athanasius returns to the city, Gregory insists that the bishop's exile, as well as the exile of all his fellow Nicene bishops, was an "illustrious banishment." Gregory states, "Our champion was restored from his illustrious banishment, for so I term his exile [ek tēs kalēs ekdēmias ho athlètēs houtō gar egō kalō . . . phygēn]" (Orat. 21.27). To be clear, Athanasius is no vagabond wandering aimlessly, like Oedipus; he is a victim of persecution who takes full advantage of his circumstance by providing others with pastoral direction. Athanasius's exile is indeed a desert askesis, but a temporary one. James Goehring has noted elsewhere that Gregory does not see the desert as a classical cultured retreat (otium liberale). ${ }^{45}$ Much like his description of the

44. Brakke, Athanasius and Asceticism, 14.

45. Goehring, "Dark Side of the Landscape" 445-46. 
desert in his letter to Basil (Ep. 4), the desert is filled with spiritual dangers and hardships. According to Gregory, the desert is a training ground from which the bishop ultimately must return. ${ }^{46}$

To prove this point, in the final section of the oration, Athanasius's illustrious banishment is quickly overshadowed by a lengthy and elaborate description of his reentry into the city. ${ }^{47}$ Gregory depicts Athanasius's return much like Christ's procession into Jerusalem: "he rode upon a colt"; "he is welcomed with branches of trees"; and there "were those who went before with shouts and followed with dances" (Orat. 21.29). Once reinstated, Athanasius also "cleansed the temple of those who made merchandise of God" and "those who had been wronged he set free from oppression" (Orat. 21.30). ${ }^{48}$ The savior of Alexandria has returned once more and is more glorious than before.

For Gregory, Athanasius is the ideal monk-bishop. His exile is not physically bound to the desert, but the desert is carried with him into the active life of the city. Truth is first affirmed in the desert and then put to use in the city center. In the final paragraphs of the oration, Gregory draws us back to another city, prompting us to look to Nicaea. He is careful to note that the most important work Athanasius did was for the Nicene cause. It is for this reason alone that Athanasius suffered his illustrious banishment. Athanasius's temporary withdrawal and triumphant return were ultimately designed for the greater good of orthodoxy. This message is not meant for Alexandria alone but is carried into and proclaimed in that beacon of Nicene orthodoxy, Constantinople.

\section{CONCLUSION}

Gregory reimagined Athanasius's exile as an ascetic retreat to reaffirm this fleeing bishop's reputation as a persecuted orthodox figure. He also used Athanasius's exilic discourse to emphasize his return to the city as a transformed man. The true Alexandrian bishop was ultimately made over into the ideal monk-bishop ready to take up his episcopal throne after his illustrious banishment. Gregory transformed that heterotopic vision of the desert into an embodied state of active civic engagement. The monk-bishop serves as a model for the new ecclesiastical ideal: the true monk-bishop easily transitions back into the active life of the city because he holds onto the solitary life of the desert.

It is in Gregory's funerary oration on Basil of Caesarea that we begin to see how Christian flight is intimately wedded to ascetic training. Only when we accept

46. Gregory of Nazianzus, Letter to Basil, Ep. 4.

47. In this last section, Gregory expands upon Athanasius's reflection on his return to Alexandria after his second exile in 346 in $H$. Ar. 25.

48. Gregory does take note of one last exile under Julian but does not include Athanasius's exile under Jovian. 
Gregory's logic is the bishop capable of taking on his heretical foes. In his efforts to promote and secure Nicene orthodoxy, Gregory of Nazianzus makes use of Nicaea's most ardent defender, Athanasius of Alexandria. Unlike Athanasius, however, Gregory had to stress the impermanence of exile. He did this by making it clear that a bishop's flight was never intended to be an end in itself. Basil's greatest triumphs are brought about in Caesarea, and Athanasius's flight is significantly overshadowed by his return. Gregory's emphasis on return was a litmus test not just for Basil and Athanasius but for later bishops as well. If a bishop found himself exiled, his orthodoxy was affirmed by his glorious return. For it is clear that the orthodox bishop must live on not in the desert but firmly seated on his episcopal throne.

Persecution continued to play an important role in legitimizing a forced departure, much as Athanasius argued. The legacy of imperial persecution remained a powerful one. Any bishop under threat could easily invoke this claim, as we saw with Demophilus's reference to Matthew 10:23. As later pro-Nicene historians would see it, Demophilus does not return, and that is proof enough that his flight is no illustrious banishment. Gregory effectively assembled several important components, such as Christian flight, persecution, ascetic training, and return, in order to create an orthodox formula.

Gregory's panegyric on Athanasius (and his exile) set a rhetorical standard that strategically aligned Constantinople with Alexandria. This alliance would remain a contested one as Antiochene politics continued to clash with Alexandrian power plays. It is only in hindsight and with the recovery of the memory of John Chrysostom, another fleeing bishop of Constantinople, that the battle for the Athanasian legacy will once again play a significant role in the pro-Nicene narrative. In the next chapter, we will explore how John Chrysostom's identity as an exile and his theory of Christian flight posed a significant problem when compared with Gregory's formula. Episcopal exile continued to put orthodoxy at risk, particularly when there was no return in sight. 